\title{
LOKALITAS STRUKTUR \& MATERIAL KONSTRUKSI RUMAH ADAT SAPO BATTOA DESA KALUPPINI, KABUPATEN ENREKANG, SULAWESI SELATAN
}

\author{
Zulkarnain AS ${ }^{* 1}$, Mutmainnah ${ }^{2}$ \\ Jurusan Arsitektur UIN Alauddin Makassar, Jurusan Arsitektur UIN Alauddin Makassar \\ e-mail: *1 zoelarch@gmail.com, ${ }^{2}$ mutmainnah.sudirman@uin-alauddin.ac.i.
}

\begin{abstract}
Abstrak_Pengaruh lingkungan dan interaksi sosial antara satu kelompok dengan yang lain menghasilkan aturan yang terwujud dalam sebuah tatanan nilai-nilai aturan budaya, tertuang dalam wujud fisik yang tentunya selalu menyesuaikan terhadap lingkungan sekitarnya. Aturan nilai budaya dalam wujud fisik menghasilkan kebiasaan atau tradisi, dalam wujud kearifan berarsitektur terhadap bagian bagian konstruksinya dalam pemanfaatan teknologi berupa peralatan, sistem sambungan dan material konstruksi setempat. Kearifan lokal inilah yang tentunya memiliki nilai tradisi dan aturan yang selalu menjaga Desa Kaluppini yang kaya akan nilai budaya, sejarah, keragaman suku dan arsitektur rumah adat tradisionalnya. Arsitektur rumah adat Sapo Battoa merupakan salah satu cerminan lokalitas yang memiliki tatanan aturan nilai budaya setempat dan memiliki nilai keseimbangan antara lingkungan dan tempat tinggalnya. Lokalitas Arsitekturnya terlihat dari struktur dan konstruksi yang ada pada setiap bagian-bagian elemen konstruksi Sappo Battoa. Objek rumah adat ini yang dijadikan objek untuk di teliti terhadap bagian-bagian elemen Lokalitas struktur dan material konstruksinya.
\end{abstract}

Kata kunci : Struktur Konstruksi; Lokalitas; Rumah Adat Tradisional.

Abstrac_The influence of environment and social interaction between one group with the other form embodied in a cultural value order, contained in a physical form that is always adapted to the surrounding environment. In the form of the wisdom of architecture to the part of its construction in the utilization of technology, equipment and construction. This local wisdom, of course, has a tradition and rules that always keep the village of Kaluppini rich in cultural values, history, ethnic diversity and architecture of traditional custom homes. The architecture of Sapo Battoa traditional house is one of the reflections of the locality that has the order of cultural rules and has a balance between the environment and the residence. Locality of Architecture seen from the structure and construction that exist in every part of construction elements of Sappo Battoa. Object of this custom house which is used as an object to be meticulously against the elements elements Lokalitas structure and construction materials.

Keywords: Construction; Locality; Traditional House. 


\section{PENDAHULUAN}

Sebuah karya arsitektur yang merupakan reprentasi dari kehidupan budaya dan sosial. Sama halnya dengan rumah adat Sapo Battoa yang berda di Desa Kaluppini, Kabupaten Enrekang tidak hanya dilihat sebagai sebuah objek melainkan juga sebagai suatu produk dari proses berbudaya yang telah mengalami banyak penyesuaian terhadap kondisi masyarakat dan kondisi alam. Kondisi masyarakat yang ada pada lingkungan Desa Kaluppini yang memiliki kebudayaan yang kental dan menjadi cikal bakal retendensi dominan masyarakatnya yang berpegang teguh pada warisan budaya leluhur. Tampak jelas pada bangunan rumah adat Sapo Battoa yang memanfaatkan material konstruksi dari vegetasi yang tersedia disekitarnya dan sudah dipercaya memiliki kekuatan, baik struktur konstruksinya maupun adat kepercayaan setempat.

Menurut Koentjaraningrat (2009), dalam penyelesaian teknologi membangun rumah, bentuk serta model bangunannya lebih cenderung memilih bentuk rumah bertiang atau di atas tiang (pile dwelling) dengan sistem sambungan yang memanfaatkan material lokal setempat mulai dari material pondasi, dinding, dan atap serta alat penyambung konstruksinya. Arsitektur merupakan sebuah karya yang bukan kebutuhan mendasar akan bangunan fisik saja, tetapi dilandasi oleh perhitungan-perhitungan rasional, dan arsitektur ini dapat menciptakan hubungan secara vertikal dengan pencipta-Nya dan spritiual antara manusia dengan alam semesta, serta hubungan sosial budaya antara sesama manusia dengan alam semesta, serta hubungan sosial budaya antar sesama (Bano Et Al, 1992).

Pada rumah adat Sapo Battoa Kaluppini, setiap pengerjaan terhadap penyelesaian struktur konstruksi bangunannya tidak terlepas dari pemahaman secara alamiah masyarakatnya dalam menanggapi setiap bagian-bagian konstruksinya terhadap kepercayaan leluhurnya. Pemahaman berarsitektur struktur konstruksinya merupakan pemahaman secara turun - temurun dalam setiap proses konstruksinya yang harus sesuai dengan nilai aturan adat kepercayaan Desa Kaluppini. Tidak hanya itu, pemahaman akan terselenggaranya bentuk-bentuk bangunan arsitekturnya dimaknai sebagai sesuatu yang sakral dan terbentuk dari sejarah, tradisi, dan adat budaya Desa Kaluppini, Kabupaten Enrekang, Sulawesi Selatan. Sejatinya Rumah Adat Kaluppini (Sapo Battoa) Merupakan Warisan budaya luhur dari Keluarga Besar Kerajaan Enrekang atau yang biasa dikenal dan disebut Tumanurung yang Sembilan bersaudara. Oleh sebab itu, Setiap elemen pembentuk rumah adat Kaluppini (Sapo Battoa) Syarat akan makna dan filosofi yang sesuai dengan kebudayaan dan kepercayaan masyarakat setempat.

\section{METODOLOGI}

Untuk mencapai hasil penelitian yang sesuai pendekatan arsitektur lokal, metode yang digunakan dalam penelitian ini yaitu ;

1. Studi literatur untuk mempelajari Karakteristik Rumah Adat dan elemen - elemen pembentuk rumah adat Kaluppini (Sapo Battoa). Untuk studi literature di ambil dari beberapa sumber (Buku dan Internet)

2. Studi banding tema sejenis sebagai perbandingan jurnal nantinya. Data ini di ambil dari Jurnal dengan Tema Sejenis.

3. Survey lapangan ke lokasi Objek penelitian, untuk mengetahui kondisi Eksisting, Struktur Konstruksi, Lokalitas, bentuk dan model bangunannya yang dapat menjadi Objek penelitian.

4. Hasil survey, menghasilkan data maupun informasi terkait dengan arsitektur tradisional rumah Adat Kaluppini (Sapo Battoa). 


\section{HASIL DAN PEMBAHASAN}

\section{A. Gambaran Umum Lokasi}

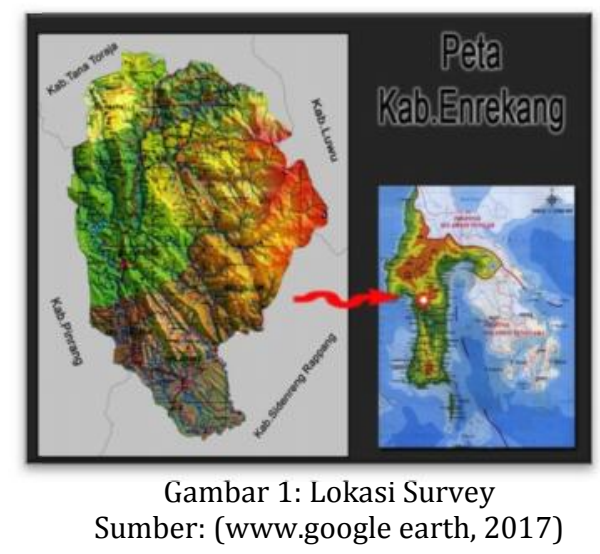

Desa Kaluppini terletak di Kabupaten Enrekang terletak di kaki Gunung Latimojong, Provinsi Sulawesi Selatan. Kampung ini berjarak sembilan kilometer dari Ibu kota Kabupaten Enrekang dan dapat ditempuh menggunakan kendaraan roda dua selama 30 menit. Masyarakat adat Kaluppini yang berpenduduk 1.000 orang menempati kawasan pegunungan Latimojong di ketinggian $800 \mathrm{mdpl}$ hingga $1.200 \mathrm{mdpl}$. Wilayah adat Kaluppini meliputi lima desa yakni, Tokkonan, Rosoan, Tobalu, Lembang, dan Kaluppini.

\section{B. Rumah Adat Tradisional Sapo Battoa}

Sebuah karya arsitektur yang merupakan reprentasi dari kehidupan budaya, rumah adat Sapo Battoa yang berada di Desa Kaluppini, Kabupaten Enrekang tidak hanya dilihat sebagai sebuah objek melainkan juga sebagai suatu produk dari proses berbudaya yang telah mengalami banyak penyesuaian terhadap kondisi masyarakat dan kondisi alam. Dengan mengkaji rumah adat Sapo Battoa, secara tidak langsung kita akan memahami bagaimana masyarakat di Desa Kaluppini, Kabupaten Enrekang yang membentuk jati diri sesuai dengan pandangan hidup mereka dan mengapresiasikannya ke dalam wujud arsitektural.

Secara sederhana rumah adat sappo battoa sebagai rumah tradisional di Desa Kaluppini, Kabupaten Enrekang adalah rumah tinggal yang dimiliki oleh keluarga besar raja atau yang biasa disebut Tumannurung. Berdasarkan sejarah rumah adat ini merupakan tempat tinggal sembilan bersaudara yang merupakan tonggak sejarah di Kaluppini. Sembilan bersaudara yang bahkan menyebut namanya pun dikeramatkan oleh masyarakat setempat merupakan awal kisah dari sejarah masyarakat adat Kaluppini. 


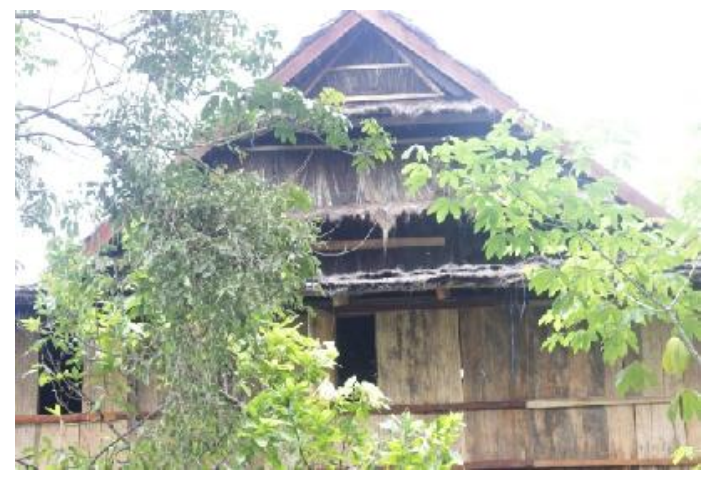

Gambar 2: Sapo Battoa

(www.google.com, 2017)

Menurut Cerita salah satu Imam Desa Kaluppini menyebutkan bahwa sembilan bersaudara tersebut dilahirkan dari rahim seorang gadis di kampung Kaluppini. Namun prosesnya tidak lazim seperti pada proses lahirnya anak manusia pada umumnya. Enam dari sembilan bersaudara itu kemudian meninggalkan Kaluppini dan mendiami beberapa wilayah lainnya. Sedangkan tiga lainnya bertahan di Kaluppini. Rumah adat Sapo Battoa yang berdiri di belakang mesjid. Mempunyai 5 petak/lontang dan 33 tiang. Di atas rumah yang telah dibagi menjadi 5 bagian yaitu, tempat Tomannurung, Pengangku Ada', Pengangku Agama (Tomakaka), Khali dan Imam, serta Puang. Di bagian atas pula terdapat 3 tingkatan yaitu kandawari (stage) tempat raja, tambing (tempat Rakyat) dan pelataran bawah. Rumah ini adalah tempat bermusyawarah apapun yang akan dilakukan di Desa Kaluppini. Tambing adalah tempat dalam sebuah rumah yang membedakan rumah adat ini dengan daerah lain di Sulawesi Selatan. Sapo Battoa mempunyai tempat tersendiri yang disebut Pa'nenean dengan tinggi $50 \mathrm{~m}$, panjang $2 \mathrm{~m}$ dan lebar 3m. Semua rumah warga Desa Kaluppini dan rumah adat Sapo Battoa menghadap ke arah utara, salah satu alasannya adalah untuk tidak melaksanakan salat menghdap ke dapur dan ke pintu wc/ kamar mandi.

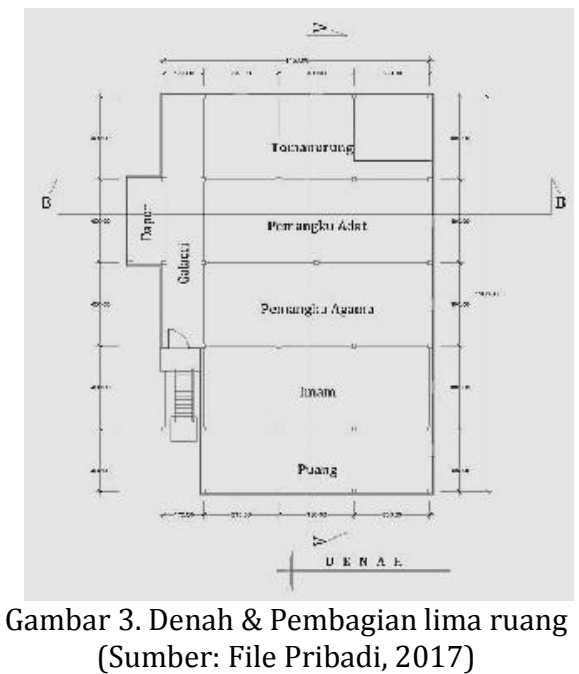

Ruang tamu Sapo Battoa kerap kedatangan tamu raja enrekang untuk menghadiri pertemuan kerajaan. Para tamu yang datang akan dipersilahkan duduk pada ruang. Ruang tamu Sapo Battoa kerap kedatangan tamu raja enrekang untuk menghadiri pertemuan kerajaan. Para tamu yang datang akan dipersilahkan duduk pada ruang. Pada ruang tamu terdapat tiang yang 
berbeda sendiri yang disebut posi bola atau inti rumah. Posi bola tersebut terbagi menjadi 2 bagian yang disambung menggunakan jenis kayu yang berbeda, Bagian atas Posi bola mengguna kan Kayu namgka, dan bagian bawah menggunakan kayu raja. Posi bola ini banyak dipenuhi dengan ukiran-ukiran yang dikreasikan untuk menambah estetika posi bola.
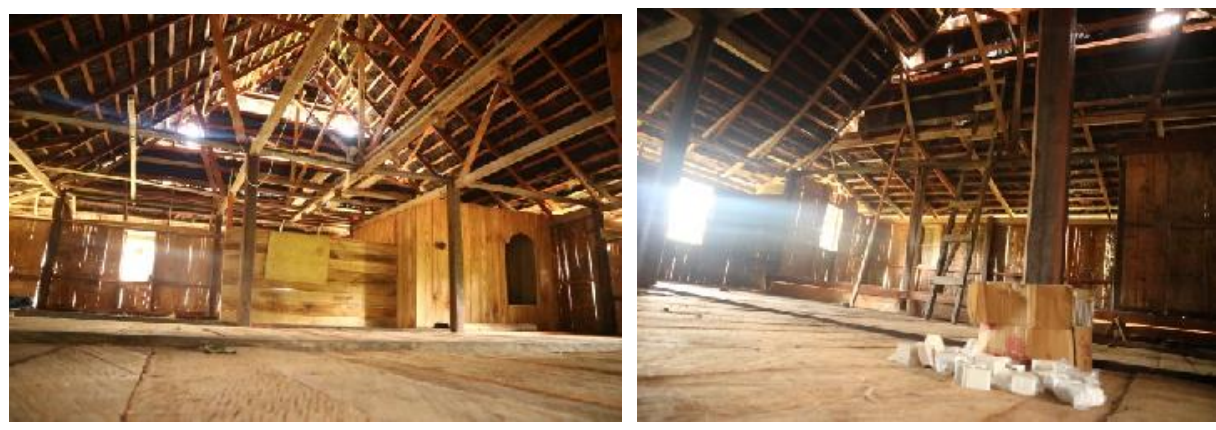

Gambar 4: Ruang tamu rumah adat Sapo Battoa setelah renovasi (Sumber: Dok. Pribadi, 2017)

Dipinggir ruang tamu yang terdapat sebuah kayu panjang antara daerah ruang tamu yang lebih tinggi dengan daerah bawah yang disebut Patta hal tersebut dipercayai bahwa tidak boleh diinjak ataupun diduduki. Hal itu dikarenakan agar seseorang yang memasuki ruang tamu dapat duduk lebih sopan. Sedangkan Kalaccia merupakan batas atau pembeda elvasi lantai dalam suatu ruangan dan sebagai pembeda jenis ruangan yang terdapat dalam rumah adat Sapo Battoa.

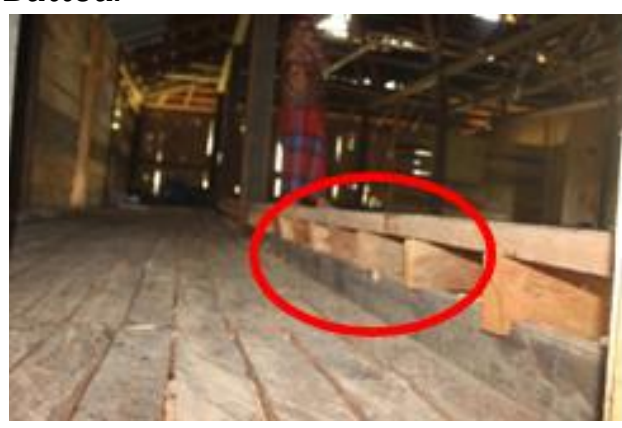

(a)

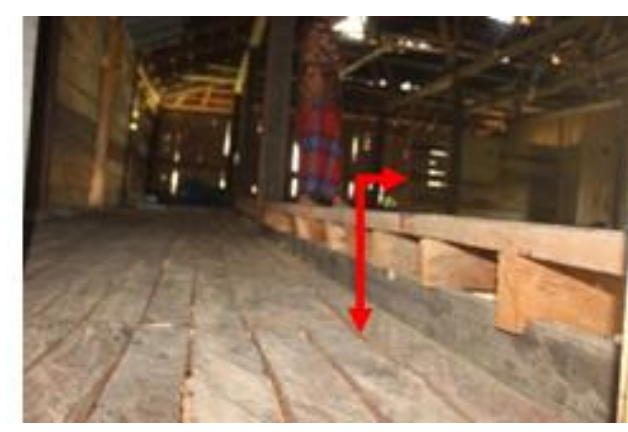

(b)

Gambar 5: Patta (a) Tambing (b)

(Sumber: Dok. Pribadi, 2017)

Tempat Tommanurung rumah adat Sapo Battoa ini terbagi menjadi lima bagian khusus. Bagian pertama tempat tommanurung, yang memiliki ruang khusus ditempat duduknya dan ditempat peristirhatannya. Lalu,Pengangku Ada', Pengangku Agama (Tomakaka), Khali dan Imam, serta Puang. 


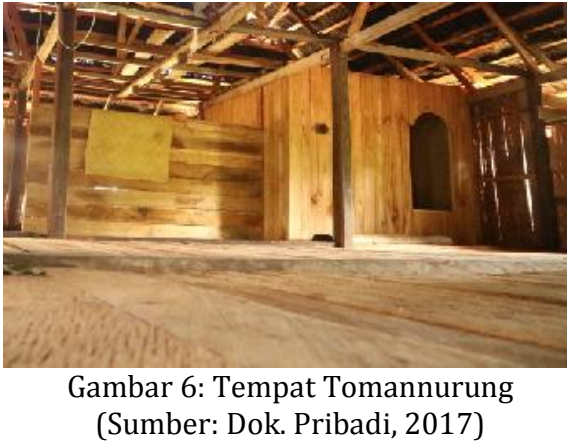

\section{Struktur Rumah Adat Sapo Battoa}

Pada stuktur bawah rumah adat Kaluppini terdapat kolom rumah Rumah Adat Sapo Battoa (pake'deng) berukuran 10m X 19 m dengan jumlah tiang 20 buah dengan ukuran yang berbeda-beda dikarenakan untuk menghasilkan balok (tomakbau') yang berukuran sama secara keseluruhan sangat sulit pada saat itu. Karena dalam proses pembuatan tiang hanya menggunakan parang untuk mengikis kayu hingga berbentuk balok yang diinginkan. Jadi, bekas-bekas kikisan masih jelas terlihat disetiap kolom pada rumah adat Rumah Adat Sapo Battoa .

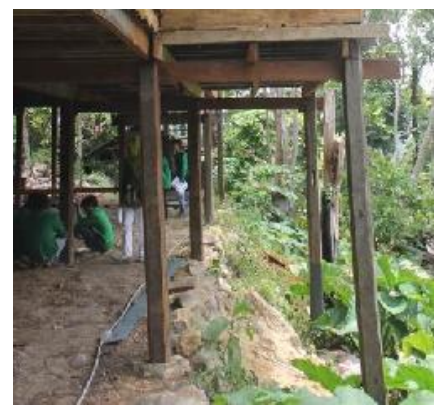

(a)

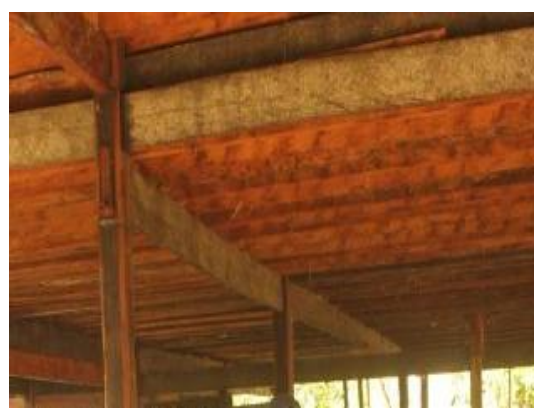

(b)

Gambar 7: kolom rumah / pake'deng (a) balok lantai/tomakoa' (b)

(Sumber: Dok. Pribadi, 2017)

Kemudian struktur tengah rumah adat sappo Battoa terdapat enam bukaan jendela, satu pintu, dan terdapat satu tangga pada bagian depan bangunan sebagai akses naiknya orang ke rumah adat Sapo battoa. Tangga tersebut tidak terlalu tinggi maupun curam dan mempunyai pegangan atau relling yang disebut corcoran.

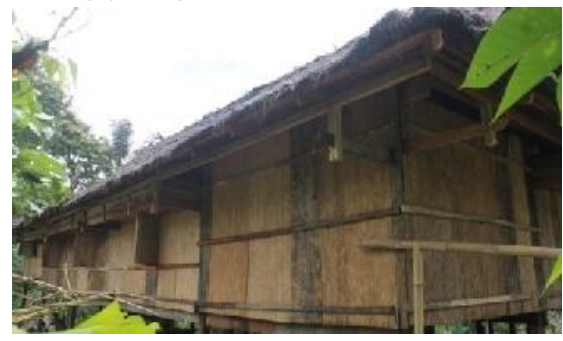

(a)

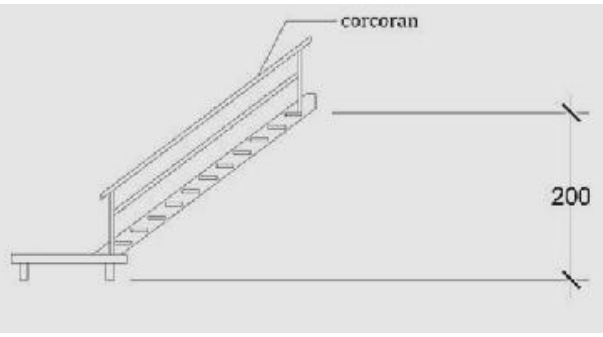

(b)

Gambar 8: dinding dan jendela rumah adat Sapo battoa (a) relling / corcoran rumah adat Sapo battoa (b) (Sumber: Dok.Pribadi, 2017)

Adapun susunan rangka atapnya sesaui dengan penamaan bahasa Desa Kaluppini yaitu tiang raja (Seu'du), gording (Pakkadilang), kasau (kasau), skor angin (Pangtuppa), overstek (Tapatta goa), Pengikat atap (Joli), dan busaran (jakka-jakka). Adapun ruang tambahan untuk 
penyimpanan barang yang terdapat dilantai tiga atau daerah sekitar atap yang biasanya disebut tapan. Pada daerah timpa lajanya disusun sebanyak 2 tingkatan yang biasa disebut timbo.

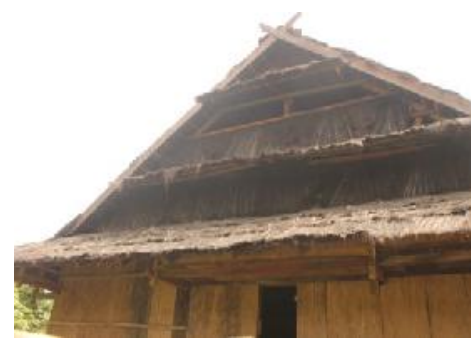

(a)

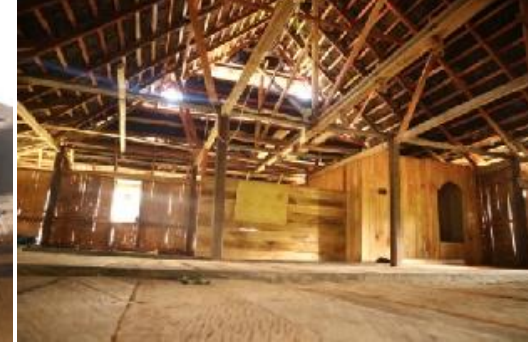

(b)

Gambar 9: Atap Tampak dalam dan Depan

(Sumber: Dok. Pribadi, 2017)

\section{Bahan Material Konstruksi}

Jenis bahan material untuk sebuah rumah Sapo Battoa masih berasal dari lokasi sekitar pembangunan rumah adat Sapo Battoa tersebut. Dengan beberapa material yang dipilih khusus tentunya untuk bagian-bagian konstruksi yang berhubungan langsung dengan tanah. Bahan material kontruksi pada kolom (posi bola) tersebut terbagi menjadi 2 bagian yang disambung menggunakan jenis kayu yang berbeda , Bagian atas Posi bola mengguna kan Kayu nangka, dan bagian bawah menggunakan kayu raja. Posi bola ini banyak dipenuhi dengan ukiran-ukiran yang dikreasikan untuk menambah estetika posi bola. Pada kolom dan balok menggunakan bahan material dari kayu kayu biasa, kayu panasa, dan kayu mahoni.

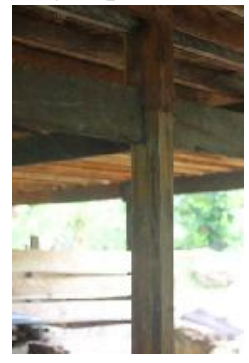

(a)

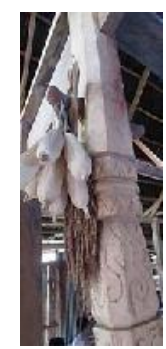

(b)

Gambar 10: Posi Bola bagian atas (a) Posi Bola bagian bawah (b)

(Sumber: Dok. Pribadi, 2017)

Pada struktur tengah rumah adat Sapo Battoa yaitu jendela dan tangga menggunakan bahan material konstruksi berupa kayu biasa. Bahan material pada dinding rumah adat Sapo Battoa terbilang unik karena terbuat dari kayu yang berasal dari pohon banga yang proses pembuatannya dengan cara ditebang lalu dikeringkan sampai menimbulkan tekstur yang menjadi ciri khas pohon banga. Menurut penuturan Imam Desa Kaluppini bahwa material kayu banga merupakan bahan material konstruksi yang hanya digunakan di Desa Kaluppini karena kayu banga merupakan pohon lokal khas Enrekang. Ditambahkan pula bahwa dinding dari kayu banga akan awet selama puluhan tahun apabila tidak terkena air.

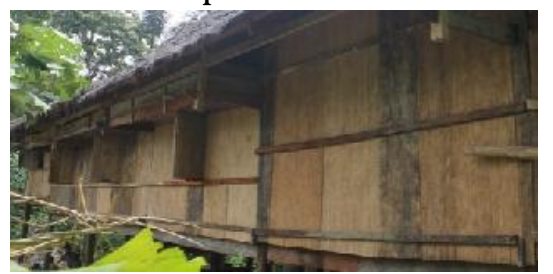

Gambar 11: Dinding dan Jendela Rumah Adat Sapo Battoa

(Sumber: Dok.Pribadi, 2017) 
Pada bagian atap rumah adat Sapo Battoa dibagian struktur penyusun rangka atapnya menggunakan material kayu biasa, sedangkan pada bahan atap terbuat dari bahan ijuk yang masih sangat tradisional.

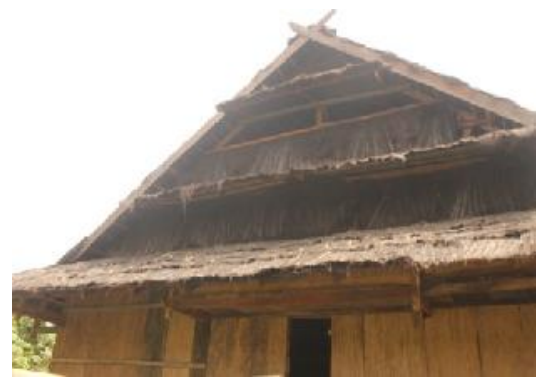

Gambar 12: Tampak depan atap Sapo Battoa (Sumber: Dok.Pribadi, 2017)

\section{KESIMPULAN}

Rumah adat Kaluppini (Sapo Battoa) merupakan warisan budaya masyarakat Enrekang yang sampai saat ini sangat dijaga dan juga disakralkan. Lokalitas bangunan dapat terlihat dari model struktur dan konstruksi yang tertuang dalam unsur budaya, yakni bahasa, pengetahuan, teknologi dan kesenian Penilaian secara fisik dapat memperoleh makna tentang kedudukan sosial dalam struktur organisasi adat serta fungsi bangunan. Lokalitas tercermin pada salah satu unsur dalam kebudayaan yaitu teknologi yang mencakup sistem sambungan, material serta ornament bangunan Arsitekturalnya yang terbentuk dan terbangun atas dengan dasar yang telah diwariskan secara turun-temurun oleh leluhur Desa Kaluppini. Setiap material yang ada di rumah adat Kaluppini bukan tanpa arti dan makna diletakkan begitu saja tetapi memiliki nilai kesakralan sendiri yang begitu dijaga oleh pemangku adat dan juga masyarakat setempat. Sebuah karya Arsitektur yang nyata dari ratusan tahun yang lalu dan masih dijaga original bentuk dan juga pemaknaan dari setiap elemen rumah Adat Kaluppini (Sapo Battoa).

\section{DAFTAR REFERENSI}

Bano R.M.Z, Betang A, Y,. Fernandez R, Bell J., Fanggidae I., Toka E., Herewilla J., Manu A. K., Titi Ch., 1992. Laporan Studi Arsitektur Vernakuler. Universitas Widya Mandra Kupang - NTB.

Koenjtaranigrat. 2009. Pengantar Ilmu Antropologi. Penerbi Rineka Cipta.

Ira mentari. 2012. Menggali makna arsitektur vernakular. LANTING Journal Architecture.volume 1.

Budi Sudarwanto \& Bambang Adji Murtomo.2013.Studi Struktur dan konstruksi

bangunanTradisional rumah "Pencu" di Kudus. Ikatan Peneliti Lingkungan Binaan

Indonesia.Vol2 No.1

\section{WEBSITE}

Muharram, Rizqi Syahrul. 2010. Arsitektur Tradisional.[online] (http://architecturevrnacular.blogspot.com./2010/01/Tradisional.html, Diakses tanggal 18 Mei 2017)

Kompas. 2014. Menggali kembali rasa arsitektur lokal. [online] (http://infoklasika.print.kompas.com/menggali-kembali-rasa-arsitektur-lokal,diakses pada tanggal 29 Mei 2017)

Blogspot 2011. Perkembangan arsitektur tradisional. [online] 
(http://kebudayaankesenianindonesia.blogspot.co.id/2011/04/perkembangan-arsitekturtradisional-di.html? $\mathrm{m}=1$ /diakses pada tanggal 29 Mei 2017)

Yulianus. 2012. Arsitektur vernakular dan arsitektur. [online]

(http://thalesyulianus.blogspot.co.id/2012/05/arsitektur-vernakular-dan-arsitektur.html?m=1/ Diakses pada tanggal 29 Mei 2017)

Issue. 2016. Architecture first society part 1. . [online]

(https://issuu.com/aveharysakti/docs/architecture_first_society_part_1/diakses pada tanggal 01 Juni 2017) 